\title{
European Promises: Policy Options of Eastern Partnership Policy ${ }^{1}$
}

\author{
Žilvinas Martinaitis \\ Institute of International Relations and Political Science, \\ Vilnius University \\ Vokiečiu g. 10, \\ Vilnius LT-01130, Lithuania \\ E-mail: z.martinaitis@gmail.com
}

Abstract: The article seeks to assess policy options of the Eastern Partnership Policy in stimulating long-term change in the partner countries. It argues that the policy has limited power to directly promote consolidation of democratic and market economy institutions or implementation of sectoral reforms. This is due to the embeddedness and mutual reinforcement of existing institutions in the partner countries. Instead, the Eastern Partnership Policy can create new dynamics of change by altering the outcomes of day-to-day interactions of a large number of individuals and organisations. In this regard, removal of barriers to travel, trade and participation in the EU programmes is an overdue (albeit too small) step in the right direction.

Keywords: Eastern Partnership Policy, governance, new institutionalism

\section{Introduction}

Eastern Partnership (EaP) which represents the Eastern dimension of European Neighbourhood Policy (ENP) was launched in 2009 to accelerate political association and economic integration between the EU and six partner countriesArmenia, Azerbaijan, Belarus, Georgia, Republic of Moldova and Ukraine.

1 This research was supported by a Marie Curie International Research Staff Exchange Scheme Fellowship within the 7th European Community Framework Programme. 
The EaP aims to achieve its objectives by promoting institutional change in the partner countries, i.e. by fostering democracy, rule of law, human rights as well as supporting implementation of reforms in mutually agreed areas, such as asylum, standards, state aid and the like. Progress, however, has been mixed. On the one hand, signing of association agreements and establishment of deep and comprehensive free trade areas (DCFTA) ${ }^{2}$ with Georgia, Moldova and Ukraine in 2016 provide evidence of success. On the other hand, implementation of the agreements remains challenging (Petrov, 2016). Furthermore, there has been little if any substantial progress in deepening cooperation with Armenia, Azerbaijan and Belarus.

This paper aims to assess what should be the 'logic of intervention' of the EaP when promoting sustainable institutional change in the partner countries? From the onset, the EaP explicitly focused on Europeanisation of partnership countries, with particular emphasis on adoption of 'shared' values (democracy, protection of human rights) and sectoral reforms modelled on the EU practices. Conceptually, the early EaP was modeled on the biggest foreign policy success of the EU to date-successful transitions and subsequent accession of postcommunist states. The enlargement policy balanced the short-term costs of meeting conditionality with the long-term benefits of the EU membership. The EaP, however, included the former, but not the latter. This led Freyburg et al. (2009), Maier and Schimmelfennig (2007) and others to argue that in the absence of prospect of accession, the EU lacks leverage in fostering institutional change in the neighbourhood countries. The limitations of this approach became obvious when Ukraine refused to sign association and free trade agreement with the EU during the Vilnius summit in 2013 (Vernygora et al., 2016).

In the light of mixed success and review of the ENP in 2015, the EaP has witnessed subtle evolution in focus and logic of operation: from conditionalitybased Europeanisation of institutions and policies towards winning the "hearts and minds' of their citizens. While joint declarations of EaP summits continue to pay lip service to 'shared' values, the review of the ENP suggested that human rights and democracy will continue to be an item in political dialogue only in mutually agreed formats (Joint Communication, JOIN(2015) 50 final, p. 5). The increasing focus on the 'hearts and minds' is well reflected in the new Commission's Joint Staff Working Document (SWD (2017) 300 final), which

2 DCFTAs constitute a part of the EU Association Agreements with Georgia, Moldova and Ukraine. They allow the respective associated countries the four freedoms of the EU single market, i.e. free movement of goods, services, capital and people. Free movement of people covers visa free entry, but not necessarily entry of workers, which remains within the jurisdiction of Member States. 
emphasises the need to deliver tangible results for citizens, direct engagement with and support for civil society and business as well as targeted information campaigns. The evolving focus and approach of the EaP poses a question: why have the previous efforts largely failed to deliver sustainable change and to what extent can the new approach work?

The literature on Europeanisation beyond the EU conceptually follows the theoretical frameworks that guided the analysis of enlargement and focuses on two logics of change. First, according to the logic of consequentiality, the EU can promote change by providing sanctions or incentives that alter the costbenefit estimates of elites in the partner countries. In the context of the EaP, the explanatory power of this model, however, is limited, given the low leverage of the EU in the absence of prospect of accession (Freyburg et al., 2009; Maier \& Schimmelfennig, 2007). Second, according to the logic of appropriateness, the EU rules may be adopted because they are perceived as legitimate or relevant in tackling national challenges (e.g., through unilateral policy emulation as proposed by Lavenex \& Uçarer, 2004).

This paper seeks to contribute to the discussion by adopting an institutionalist conceptual framework, initially developed by Williamson (2000). The framework seeks to explain why institutions remain stable or change over time by analysing the interactions between four levels of institutions. Such approach is motivated by the fact that the EaP eventually seeks sustainable changes in formal and informal rules (institutions) in the partner countries. The main benefit of this specific framework is that it facilitates identification of locus of influence of the $\mathrm{EaP}$, i.e. how and what type of institutions can the EaP expect to change? Rather than providing an alternative to existing approaches, the proposed framework incorporates the analysis of mechanisms of the EU's influence and the logics of consequentiality and appropriateness by situating them within a broader institutional set-up.

\section{Types of institutions, speed and scope of change}

In line with North (1991, p. 97), institutions are defined as "humanly devised constraints that structure political, economic and social interaction". Institutions encompass formal (e.g., constitutional provisions) and informal (e.g., customs) rules. Williamson (2000) proposed grouping institutions into four levels: fundamental informal institutions (e.g., social norms and values), formal rules of the game (e.g., constitutional provisions), governance (e.g., 
sectoral policy) and rules governing day-to-day strategic interactions. Since the European Neighbourhood Policy seeks to induce institutional change, the proposed framework is useful in understanding the logic of intervention: (a) What specific institutions does the policy seek to change? (b) How and why do these institutions (with or without external pressure) change or remain relatively stable over time?

Fundamental informal institutions - cultural norms, customs, traditions, religious beliefs and values - comprise institutions at the first level. This involves (often implicit) answers to ontological (e.g., what constitutes identity of individual and society?) and epistemological (e.g., what constitutes a legitimate source of knowledge about the word?) questions as well as fundamental normative beliefs governing the behaviour of individuals, communities, etc. These sets of norms and practices differentiate cultures and civilisations. Institutions at other levels are embedded within and legitimised by fundamental informal institutionstherefore Williamson termed the first institutional level as 'embeddedness'. Beliefs and norms have an effect on what constitutional designs are deemed appropriate and how these rules should be implemented. This has important implications for comparative analysis of diverse outcomes under similar formal institutional structures. For instance, one could argue that façade democracies are logical outcomes of attempts to install democratic institutions in an unwelcome framework of informal institutions. Williamson argued that changes at this institutional level take generations to take root. Dynamics could be inspired by exogenous trends and shocks (such as wars) as well as endogenous social, economic or technological developments (e.g., urbanisation).

Institutions at the second level are composed of formal rules of the game that lay out the division of powers and structure of polity, judiciary and bureaucracy. These include constitutional norms, legal system, administrative model, etc. Peters (2012) called these 'meta-rules' to emphasise that they govern who and how can make specific decisions. Hence formal rules of the game have significant impact on the governance institutions by limiting the scope of constitutionally, administratively, etc. acceptable alternatives. As Williamson (2000, p. 596) argued, in the absence of strong external shocks (e.g., revolutions), endogenous changes at this institutional level require between 10 to 100 years.

The third institutional level is termed governance as it comprises rules governing interactions within specific policy area. Examples include education, social security, competition and other policies. They set the rules for day-today interactions of individuals and organisations as well as affect the strategies and outcomes of such interactions. Governance institutions are embedded 
within formal rules of the game. As Williamson (2000) argued, institutional change at this level can take place within 1-10 years. In the absence of external shocks, changes in the governance-level institutions can take place due to shifts in formal rules of the game (e.g., change in constitutional doctrine) or due to unsatisfactory outcomes of day-to-day interactions.

The fourth level of institutions refers to continuous day-to-day decisions and interactions. They take place within existing governance institutions that shape the pay-offs of different courses of action. At this level, agency is brought into the analysis. It helps to explain differences in strategies and (political, economic) outcomes faced by organisations that operate under the relatively similar governance structures and institutional environments.

Table 1. Institutional levels

\begin{tabular}{|c|c|c|c|}
\hline Institutional levels & Scope of rules & $\begin{array}{l}\text { Duration of } \\
\text { institutional } \\
\text { change }\end{array}$ & $\begin{array}{l}\text { Examples of EU } \\
\text { policy }\end{array}$ \\
\hline $\begin{array}{l}\text { 4. Day-to-day } \\
\text { interactions }\end{array}$ & $\begin{array}{l}\text { Govern daily } \\
\text { decisions and } \\
\text { interactions of } \\
\text { individuals and } \\
\text { organisations }\end{array}$ & Less than 1 year & $\begin{array}{l}\text { Visa-free travel, } \\
\text { more intensive } \\
\text { trade, etc. }\end{array}$ \\
\hline 3. Governance & $\begin{array}{l}\text { Govern specific } \\
\text { policy area }\end{array}$ & $\begin{array}{l}\text { Between } 1 \text { and } 10 \\
\text { years }\end{array}$ & $\begin{array}{l}\text { Transposition of } \\
\text { acquis }\end{array}$ \\
\hline $\begin{array}{l}\text { 2. Formal rules of } \\
\text { the game }\end{array}$ & $\begin{array}{l}\text { Provide the rules for } \\
\text { policy making and } \\
\text { implementation }\end{array}$ & $\begin{array}{l}\text { Between } 10 \text { and } \\
100 \text { years }\end{array}$ & $\begin{array}{l}\text { Conditionality linked } \\
\text { with adherence to } \\
\text { democratic norms, } \\
\text { respect for rule of } \\
\text { law, and human } \\
\text { rights }\end{array}$ \\
\hline $\begin{array}{l}\text { 1. Fundamental } \\
\text { informal institutions }\end{array}$ & $\begin{array}{l}\text { Provide answers } \\
\text { to ontological and } \\
\text { epistemological } \\
\text { questions }\end{array}$ & $\begin{array}{l}\text { More than } 100 \\
\text { years }\end{array}$ & \\
\hline
\end{tabular}

Source: Own compilation

The four institutional levels (summarised in Table 1) continuously interact, which explains institutional stability and change. On the one hand, complementarities between different levels of institutions explain relative stability and stickiness of formal and informal rules. The core set of rules limit the number of alternatives 
deemed acceptable at the upper levels of institutions. In this regard, fundamental informal institutions impose limits on changes in formal rules of the game, while the latter impose constraints on the scope of policy reform at governance level. Furthermore, if the outcomes of daily interactions satisfy key stakeholders, they provide support for continued stability at governance level.

As Thelen (1999), among others, argues, radical institutional change takes place during critical junctures that are created by significant economic, social, political or military shocks. They open up a short window of opportunity for relatively fast and broad change at all institutional levels. In the absence of strong shocks, institutional change takes place (although at considerably slower pace) through a feedback loop. If the outcomes of day-to-day interactions are perceived as sub-optimal, pressures to reform governance institutions and/or formal rules of the game build up (Juskow, 2008). For example, pressure to ensure more transparent and participatory governance of one policy area may over a longer period of time result in broader democratic reforms or commitment to constitutional protection of human rights can lead to shifts in the entrenched cultural norms. Hence, endogenous change starts from dissatisfaction with the outcomes of daily interactions and has potential to trickle down to the changes in other institutional layers over longer periods of time.

Furthermore, rules facilitating day-to-day interactions between different social groups and cultures may (over long period of time) create momentum for changes in fundamental informal institutions, i.e. cultural norms, customs and values. The speed and scale of change depends on the intensity and extensiveness of cross-group interactions. This could result in intercultural diffusion where the norms and values of cultures converge. Alternatively, intensifying daily interactions may lead to greater cultural divergence or re-actualisation of prior differences, if one group feels threatened by pervasive cultural influence of the other. The process of globalisation seems to have resulted in both: increased cultural convergence in some regions and deepening of cultural cleavages, reestablishment of distinct regional/religious/cultural identities in others.

The above explanation of institutional change incorporates the conceptual approaches used to explain the mechanisms of Europeanisation. In line with the logic of consequentiality, the sanctions and rewards provided by the EU have the potential to alter the perceived utility of institutions and create pressure for change. The impact of the EU incentives, however, is mitigated by the compatibility of reforms with pre-existing institutions. The larger the incentives and the higher the compatibility of proposed reforms with preexisting institutions, the higher the chances of Europeanisation. Furthermore, in 
line with the logic of consequentiality, EU rules will be viewed as legitimate and effective in tackling domestic challenges if they are compatible with existing fundamental institutions in the 'receiving' country. Lastly, institutional change can take place through norm diffusion between policy areas at the governance level or between different levels of institutions, as suggested by the model of democratic governance.
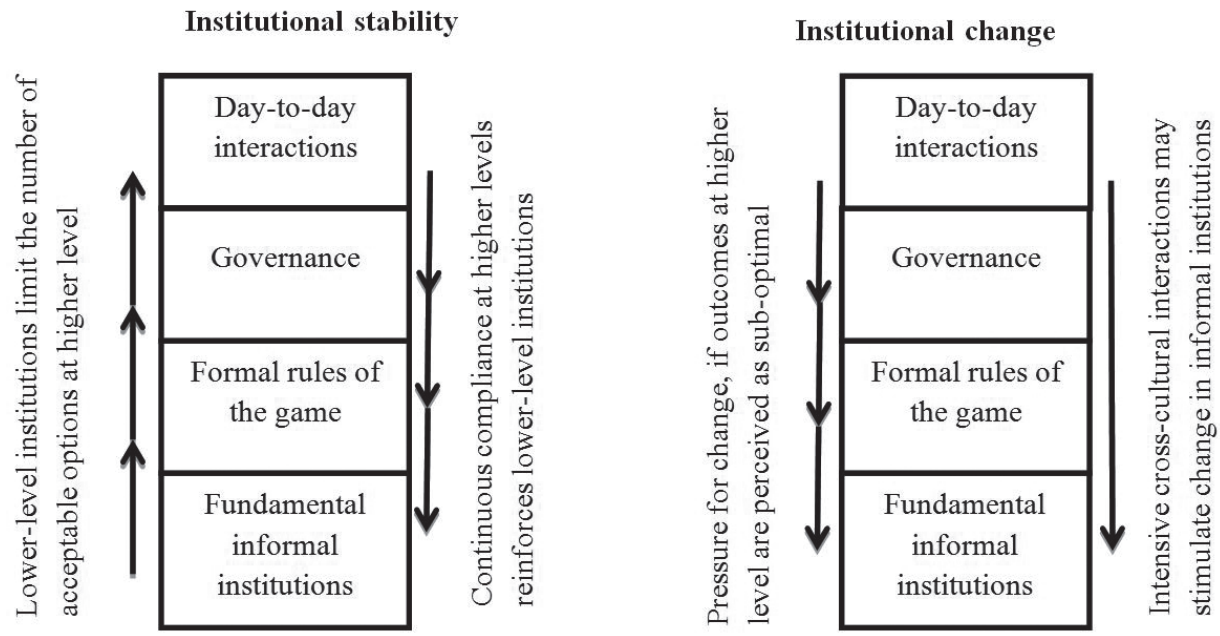

Figure 1. Institutional change

Figure 1 summarises the logic of institutional change and stability. Such framework is useful in identifying the key areas where the EaP seeks institutional change. First, it aims to stimulate change in formal rules of the game, i.e. set-up of democratic and market economy institutions, respect for human rights and rule of law. Second, sectoral cooperation focuses on governance level. Third, the EU also seeks to change outcomes of day-today strategic interactions by targeting non-state actors and fostering peopleto-people interactions. Chapters below discuss the merits and likelihood of success of these strategies. 


\section{Focus on fundamental institutions and formal rules of the game}

The ENP and the EaP are based on commitment to 'shared' values: democracy, rule of law and respect for human rights. As European Neighbourhood Policy Strategy Paper (2004) argues, these values are 'shared', because the partner countries are signatories of respective international conventions. Until 2015 adherence to these principles was a key condition for further deepening and widening of bilateral relationships. Formally agreed Action Plans not only reiterated partners' commitments to the 'shared' values, but also went into great detail in outlining specific reforms that should be carried out. Implementation was monitored via publication of annual monitoring reports that outlined areas in need for further action. Such approach closely resembled the previously applied enlargement strategy - it relied on monitoring of implementation of the Copenhagen criteria, which were used as conditionality for joining the EU.

While this proved highly effective during the enlargement process, its success as part of the ENP was limited. As the Review of the European Neighbourhood Policy (Joint Communication, JOIN(2015)50 final, p. 5) argues, it "has not proven a sufficiently strong incentive to create a commitment to reform, where there is no political will". The review also proposed that the Commission should develop new monitoring formats and that democracy and human rights should enter the discussion with partners on mutually agreed formats. Furthermore, the EU has signed association agreements and entered DCTFA with Georgia, Moldova and Ukraine - none of them are free democracies according to Freedom House (2018). Hence, the EU has drifted away from conditionality based on 'shared' values, because such policy failed to kick-start the expected changes in formal rules of the game. Why has this approach failed?

Schimmelfennig (2012) argued that the approach failed because it imposed high costs, which were not offset by the medium- to long-term benefits (such as prospect of accession). The analytical framework of this paper further suggests that conditionality based on 'shared' values can only work if the values are, at least to some extent, embedded in the institutional structure of the target countries. The accession of post-Socialist Central and Eastern European (CEE) countries was relatively fast and smooth precisely because the necessary fundamental institutions and formal rules of the game were largely in place. This is not the case for the EaP countries. Rather than being historically and culturally embedded in the West, they lie at the frontier of Huntingtonian clash of civilisations. Historically none of them had democratic experience, with the semi-exceptions of Western Ukraine and the Democratic Republic of Georgia 
(1918-1921). Attempts to establish democracy and market economy after 1991 faced numerous set-backs or outright entrenchment of authoritarian regimes. Furthermore, the EaP countries also engaged in nation-state building, which resulted in armed territorial conflicts (with the exception of Belarus).

As of 2018, Freedom House (2018) ranks four EaP countries (Armenia, Georgia, Moldova and Ukraine) as partly free and two (Azerbaijan and Belarus) as not free. Partial democracies are embedded within informal institutions. As Life in Transition survey, carried out by EBRD (2016) suggests, less than half of population in four out of six EaP countries prefer democracy to any other political system (see Fig. 2). On average, only one in three respondents in EaP preferred market economy (interestingly, this is also the case in the new EU members). Support for gender equality at a household level is also very low across the EaP countries. Clearly, one should not take these results at face value as they are subject to a number of well-known biases. Nevertheless, they are indicative of the level of support for the 'shared' values that the EU sought to promote. Experience with partial democracy may create demand for further democratisation (consider Georgia in 2004 and Ukraine in 2005 and 2014). Nevertheless, as the history shows, the shifts are not linear, unidirectional or irreversible.

Figure 2. Support for democracy, market economy and gender equality

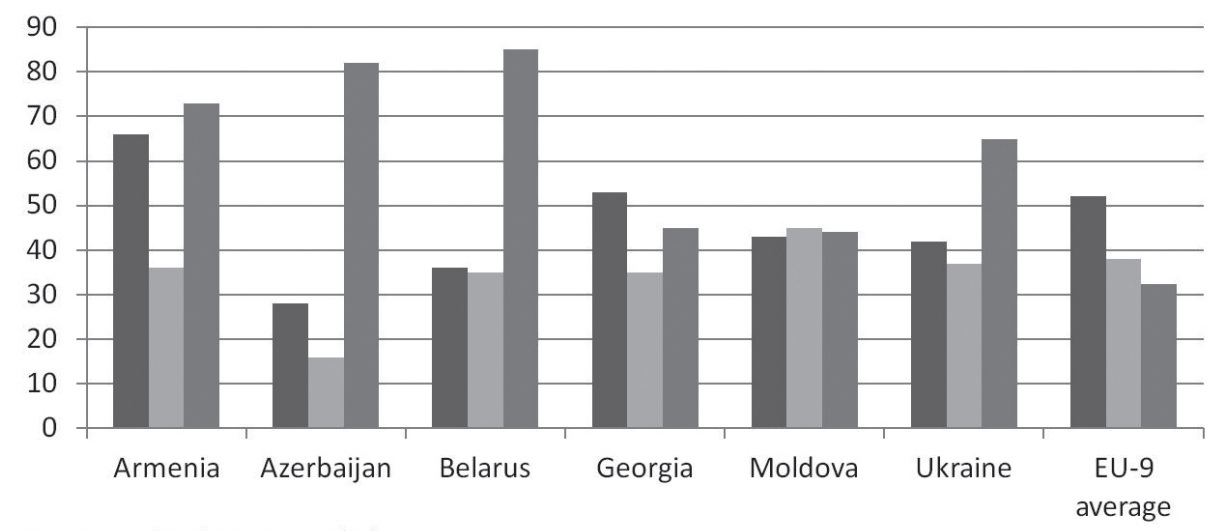

Support for democracy (\%)

- Support for market economy (\%)

Woman should do the household chores, even if her husband is not working (\% agreeing with the statement)

Source: EBRD, 2016.

Note: EU-9 include: Bulgaria, Estonia, Hungary, Latvia, Lithuania, Poland, Romania, Slovakia and Slovenia. 
To sum up, conditionality-based promotion of 'shared' values has not been the main driving force of democratisation in Eastern Europe and beyond. At best it can sustain the existing political momentum behind reforms and/or facilitate consolidation of the progress already achieved in the partially free countries. In the face of limited effectiveness, it seems justified that the EU dropped adherence to 'shared' values as a precondition for further deepening of relationships.

\section{Focus on governance-level institutions}

The EaP also seeks changes in governance-level institutions, i.e. rules and standards governing specific policy area. This is driven by sectoral cooperation (ranging from energy policy to statistics, competition and trade policies), which may involve transposition of the acquis. The promise of success of incremental sectoral change is related with two main factors.

First, sectoral cooperation offers a more favourable incentives structure to the partnership countries and therefore higher chances of successful institutional change. Targeted gradual reforms at specific sectors are subject to smaller ex ante political constraints due to lower uncertainty in comparison to wholescale change in the formal rules of the game. Small changes appear easily reversible and the benefits of sectoral reform are subject to more straightforward estimates than profound reforms of power relations (Roland, 1994). The EaP countries can select sectors associated with the largest perceived pay-offs from reforms (logic of consequentiality) or where the EU rules are seen as the most appropriate for tackling domestic challenges (logic of appropriateness). To address insufficient transposition and implementation capacities, the EaP also offers targeted funding and technical assistance (Bruszt \& McDermott, 2009; Buzogány, 2013).

Second, changes in governance-level institutions (such as adoption of acquis in a specific sector) over a longer period of time could create pressures for change in formal rules of the game (i.e. democratic institutions, rule of law, etc.). There are two avenues for such change: norm diffusion and empowerment of initial winners of reforms. The democratic governance model (Lavenex \& Schimmelfennig, 2009) focuses on the former. It argues that sectoral cooperation has potential to result in an intense web of association relations between the EU and associated third countries. Sectoral acquis typically also includes "general attributes of democracy such as horizontal and vertical accountability, transparency and stakeholder and general participation" (Schimmelfennig, 2012, p. 20). If successfully adopted at sectoral level, these norms (over a longer 
period of time) may diffuse to other governance level institutions as well as formal rules of the game. Furthermore, successful sectoral reforms may create a constituency demanding broader change so as to secure the initial gains from Europeanisation.

The main weakness of this EaP strategy, however, is implementation. While adoption of sectoral reforms (or transposition of acquis) may be smooth, given the unsupportive rules of the game, its implementation may fall short of expectations. This is strongly supported by the findings in the empirical literature. Freyburg et al. (2009) investigated the adoption and implementation of acquis in water management, competition and migration (asylum) in Moldova, Morocco and Ukraine. They found that "there is a clear discrepancy between rule adoption and rule application: whereas the EU has been fairly successful in inducing the three ENP countries to adopt legislation in line with democratic governance provisions, these provisions have generally not been implemented" (Freyburg et al., 2009, p. 926). Langbein and Wolczuk (2012), analysing reforms in trade-related technical regulations, found that Ukraine's membership aspirations have inspired significant political commitment to reform, but the results of rule adoption and implementation have been mixed. Similar results are also reported by Buzogány (2013), who analysed environmental reforms in Ukraine, Ademmer and Börzel (2013), who focused on migration, energy and good governance reforms in Georgia and Armenia as well as Dimitrova and Dragneva (2013), who researched implementation of state aid regulation in Ukraine.

In sum, the EaP based on sectoral cooperation and aimed at gradual institutional change is politically more feasible and may (in the long run) produce more significant changes than conditionality linked with large-scale reforms. Implementation, nevertheless, remains a key challenge. As the empirical literature suggest, it is hindered by unsupportive rules of the game and preferential misfit between EU incentives and domestic veto players. The next section looks at the ways in which the EaP can alter the latter. 


\section{Focus on the outcomes of day-to-day interactions}

Relatively recently, the EaP has placed particular focus on creating tangible benefits for the citizens of partner countries (see Joint Staff Working Document, SWD (2017) 300 final). These include setting up of DCFTA, granting of visa free entry to the Schengen area for citizens of Georgia, Moldova and Ukraine (and possibly Armenia in the future), and opening up of Horizon 2020, Erasmus+, Creative Europe and other selected EU programmes for participants from partner countries. In a short term, these changes can alter day-to-day interactions of a large number of individuals and organisations (exporting firms, education institutions, etc.) in targeted partner countries and the EU. As the proposed conceptual model suggests, this may also have two long-term implications.

First, more intensive cross-cultural and cross-national interactions may stimulate change in informal institutions, i.e. traditions, norms and values. As the proposed conceptual model suggests, this may take decades to root. Second, new opportunities for mobility, trade and cooperation can create pressure for change at governance level institutions. There are two mechanisms of change in this respect. On the one hand, more intensive interactions and competition can expose weaknesses in national governance institutions. For example, it is likely that researchers from the partner countries will find it difficult to compete for Horizon 2020 funding (as suggested by experience of the new EU members, see Visionary Analytics, 2017). This may create pressure for reforms in national higher education and research policies so as to improve overall competitiveness of research and innovation systems. On the other hand, access to new markets, funding and mobility opportunities is likely to create a new and well-resourced class of winners from Europeanisation. This constituency will safeguard any possible future breakdown in cooperation, since they have the most to lose from a policy U-turn. Such empowerment strategy closely resembles what Youngs (2001) called EU-society links. It remains to be seen whether or not changes in the intensity and scope of cross-border interactions between individuals and organisations will lead to profound institutional change in the partner countries.

Is it likely that the shift in the EaP focus will produce the expected institutional changes? This can only happen if the association agreements and DCFTAs manage to intensify cooperation between the EU and associated countries in the form of higher volume of movement of goods, people and capital. The initial results are mixed. On the one hand, since the DCFTAs came into force, the value of exports to the EU have slightly increased (Ukraine and Moldova) or remained stable (Georgia: see Fig. 3). More generally, over the past years, the 
EU has become an increasingly important market to Georgian, Moldovan and Ukrainian exports, while their value of trade with Russia has declined. This stands in contrast with the declining value of EU imports from Azerbaijan and Belarus, which did not sign association agreements and established DCFTA.

Figure 3. Value of exports to the EU, billion euros

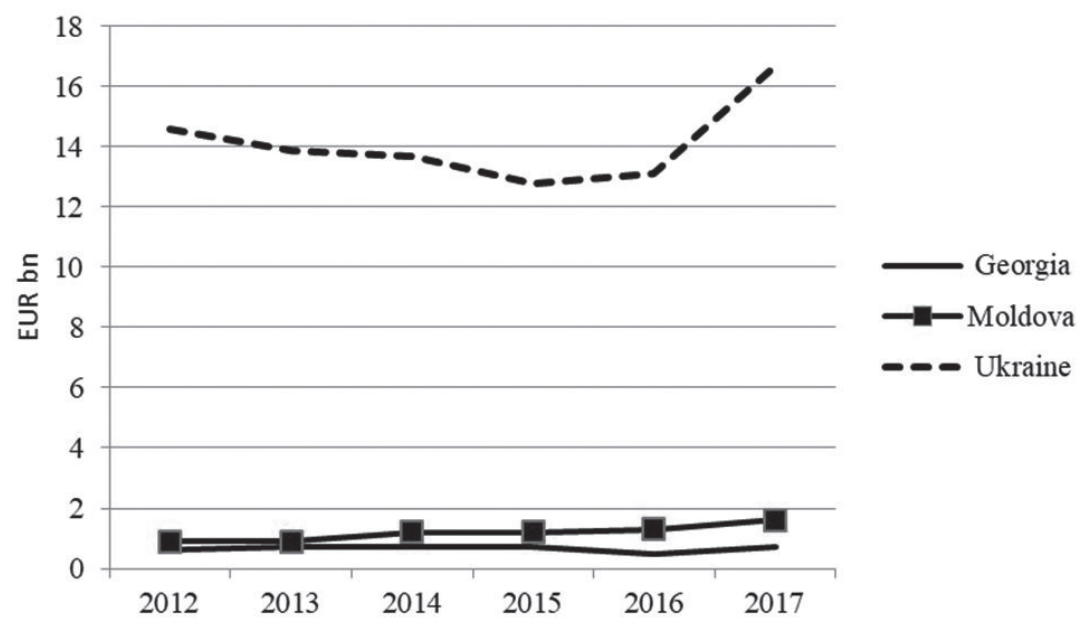

Source: Eurostat, 2018

Notes: DCFTA agreements with Georgia and Moldova provisionally entered into force in September 2014, when most of the EU tariffs for goods from the two respective countries have been lifted. The agreements entered fully into force in July 2016 (Emerson \& Kovziridze, 2016; Emerson \& Cenuşa, 2016). The DCFTA agreement with Ukraine provisionally entered into force in January 2016, although the EU largely liberalised access to its market in 2014 (Emerson \& Movchan, 2016).

On the other hand, the scale of impact of the association agreements and the DCFTAs on movement of goods, capital and people has been very small to date. In contrast to early expectations (see Muravska and Berlin, 2016) the value of exports from Ukraine and Moldova has increased rather incrementally. Furthermore, since the DCFTAs came into force, there has not been a dramatic increase in the value of the foreign direct investment (FDI) flows from the EU to the respective countries. The scale of participation in the EU programmes has also been very limited. For example, only 8,700 university students and staff from Georgia, Moldova and Ukraine participated in international credit mobility to the EU (funded by Erasmus+) in 2015-2017 (European Commission, 2018a, $\mathrm{b}, \mathrm{c})$. In relative terms, on average there were only 0.1 participants per 1,000 inhabitants. 
Clearly, removal of barriers does not lead to immediate growth in the scale of flows of goods, capital and people. However, the experience of the first few years of implementation of DCFTA suggests that the scale of its impact on cooperation between the $\mathrm{EU}$ and respective $\mathrm{EaP}$ countries is too limited. If these trends continue in the future, it is questionable that the EaP will create a critical mass of stakeholders willing to commit to Europeanisation of institutions in Georgia, Moldova and Ukraine.

\section{Conclusions}

What should be the 'logic of intervention' of the EaP when promoting sustained institutional change in the partner countries? The answer developed in this paper is twofold. The first issue concerns locus of intervention. Embeddedness and mutual reinforcement of institutions explain their stability and resistance to change. This is why efforts to promote democratic reforms (changes in formal rules of the game) cannot create new dynamics unless such efforts are supported by dominant norms and values (or fundamental informal institutions). Similarly, mutually agreed sectoral reforms (change in governance institutions) suffer from implementation deficit to the extent that they are not compatible with the existing 'rules of the game'. Instead, the paper argues that the EaP can stimulate new dynamics of institutional change by altering the outcomes of day-to-day interactions of large number of individuals and organisations. Such focus of intervention can facilitate change in fundamental informal institutions as well as create pressure for sectoral reforms. In this regard, removal of barriers to travel, trade and participation in the EU programmes is an overdue step in the right direction.

The second issue concerns the mode of intervention. Conditionality-based approach (or 'more for more' principle) has historically put the EU in an asymmetrically dominant position vis-à-vis partner countries: the latter bear the costs of change as well as face uncertainties regarding any future benefits. In the absence of prospect of accession it is not likely to produce any substantive effects, as this and other papers have argued. An alternative approach involves provision of targeted benefits by the EU in return to soft political commitment to further cooperation and reform. The shift in the role of the EU from asymmetric power to asymmetric donor may seem unwelcome. Furthermore, weakening of democratic conditionality may be not supported by the fundamental values and beliefs within the EU. However, given the unstable geostrategic and security 
landscape around the EU borders, this may prove as one of the few viable longterm strategic options for restoring stability and prosperity.

It remains too early to tell whether the shift towards winning the "hearts and minds' of citizens in the partner countries has created tangible benefits in terms of institutional change. However, so far the implementation of DCFTA has not resulted in significantly higher levels of cooperation and flows of goods, capital and people between the EU, on the one hand, and Georgia, Moldova and Ukraine, on the other. If these trends continue in the future, there is a risk that the EaP will fail to win the critical mass of 'hearts and minds' in the partner countries and therefore the broader objective of institutional change, such as strengthening of democracy and market economy, will remain elusive.

Žilvinas Martinaitis is an associate professor at the Institute of International Relations and Political Science in Vilnius University. He teaches policy analysis, research design and game theory. His academic interests focus on the drivers and effects of institutional change.

\section{References}

Ademmer, E. \& Börzel, T. A. (2013), 'Migration, energy and good governance in the EU's Eastern Neighbourhood,' Europe-Asia Studies, vol. 65, no. 4, pp. 581-608. https://doi.org/10.1080/09668136.2013.766038

Bruszt, L. \& McDermott, G. A. (2009), 'Transnational integration regimes as development programmes,' in L. Bruszt \& R. Holzhacker (eds.) The Transnationalization of Economies, States, and Civil Societies, New York: Springer. https://doi.org/10.1007/978-0-387-89339-6_2

Buzogány, A. (2013), 'Selective adoption of EU environmental norms in Ukraine. Convergence á la Carte,' Europe-Asia Studies, vol. 65, no. 4, pp. 609-630. https://doi.org/10.1080/09668136.2013.766039

Cirtautas, A. M. \& Schimmelfennig, F. (2010), 'Europeanisation before and after accession: Conditionality, legacies and compliance,' Europe-Asia Studies, vol. 62, no. 3, pp. 421-441. https://doi.org/10.1080/09668131003647812

Dimitrova, A. \& Dragneva, R. (2013), 'Shaping convergence with the EU in foreign policy and state aid in post-orange Ukraine: Weak external incentives, powerful veto players,' Europe-Asia Studies, vol. 65, no. 4, pp. 658-681.

https://doi.org/10.1080/09668136.2013.766040 
EBRD (2016), Life in Transition Survey. A Decade of Measuring Transition, European Bank for Reconstruction and Development. Retrieved from http://litsonline-ebrd. com/countries/ [accessed Nov 2018]

Emerson, M. \& Cenuşa, D. (2016), Deepening EU-Moldovan Relations: What, why and how? London: Rowman \& Littlefield International.

Emerson, M. \& Kovziridze, T. (2016), Deepening EU-Georgian Relations: What, why and how? London: Rowman \& Littlefield International.

Emerson, M. \& Movchan, V. (2016), Deepening EU-Ukrainian Relations: What, why and how? London: Rowman \& Littlefield International.

European Commission (2018a), Erasmus + for Higher Education in Georgia, March 2018.

European Commission (2018b), Erasmus + for Higher Education in Moldova, March 2018.

European Commission (2018c), Erasmus + for Higher Education in Ukraine, March 2018.

European Neighbourhood Policy Strategy Paper, COM(2004)373 final, Commission of the European Communities, Brussels, 12.5.2004.

Freedom House (2018), Freedom in the World 2018, Washington, DC.

Freyburg, T.; Lavenex, S.; Schimmelfennig, F.; Skripka T. \& Wetzel, A. (2009), 'EU promotion of democratic governance in the neighbourhood,' Journal of European Public Policy, vol. 16, no. 6, pp. 916-934. https://doi.org/10.1080/13501760903088405

Joint Communication JOIN(2015) 50 final to the European Parliament, the Council, the European Economic and Social Committee and the Committee of the Regions, Review of the European Neighbourhood Policy, Brussels, 18.11, 2015.

Joint Staff Working Document SWD (2017) 300 final Eastern Partnership: 20 Deliverables for 2020, Focusing on key priorities and tangible results, Brussels, 19.6.2017.

Juskow, P. J. (2008), 'Introduction to new institutional economics,' in E. Brousseau \& J. M. Glachant (eds.) New Institutional Economics: A Guidebook, Cambridge \& New York: Cambridge University Press, pp. 1-21. https://doi.org/10.1017/ CBO9780511754043.003

Langbein, J. \& Wolczuk, K. (2012), 'Convergence without membership? The impact of the European Union in the neighbourhood: evidence from Ukraine,' Journal of European Public Policy, vol. 19, no. 6, pp. 863-881. https://doi.org/10.1080/135 01763.2011 .614133

Lavenex, S. (2004), 'EU external governance in "Wider Europe",' Journal of European Public Policy, vol. 11, no. 4, pp. 680-700.

https://doi.org/10.1080/1350176042000248098 
Lavenex, S. \& Schimmelfennig, F. (2009), 'EU rules beyond EU borders: theorizing external governance in European politics,' Journal of European Public Policy, vol. 16, no. 6, pp. 791-812. https://doi.org/10.1080/13501760903087696

Lavenex, S. \& Uçarer, E. M. (2004), 'The external dimension of Europeanization: The case of immigration policies,' Cooperation and Conflict, vol. 39, no. 4, pp. 417-443. https://doi.org/10.1177/0010836704047582

Leino, P. \& Petrov, R. (2009), 'Between “common values” and competing universals the promotion of the EU's common values through the European Neighbourhood Policy,' European Law Journal, vol. 15, no. 5, pp. 654-671. https://doi.org/10.1111/j.1468-0386.2009.00483.x

Maier, S. \& Schimmelfennig, F. (2007), 'Shared values: democracy and human rights,' in K. Weber, M. Smith \& M. Baun (eds.) Governing Europe's Neighbourhood. Partners or Periphery? Manchester: Manchester University Press, pp. 39-57.

Muravska, T. \& Berlin, A. (2016), 'Towards a new European Neighbourhood Policy (ENP): What benefits of the Deep and Comprehensive Free Trade Agreements (DCFTAs) for shared prosperity and security?' in T. Kerikmae \& A. Chochia (eds.) Political and Legal Perspectives of the EU Eastern Partnership Policy, Cham: Springer, pp. 23-39. https://doi.org/10.1007/978-3-319-27383-9_3

North, D. C. (1991), 'Institutions,' Journal of Economic Perspectives, vol. 5, no. 1, pp. 97-12. https://doi.org/10.1257/jep.5.1.97

Peters, B. G. (2012), Institutional Theory in Political Science - The New Institutionalism, New York \& London: The Continuum International Publishing Group.

Petrov, R. (2016), 'Implementation of association agreements between the EU and Ukraine, Moldova and Georgia: Legal and constitutional challenges,' in T. Kerikmäe \& A. Chochia (eds.) Political and Legal Perspectives of the EU Eastern Partnership Policy, Cham: Springer, pp. 153-165. https://doi.org/10.1007/978-3-319-27383-9_10

Roland, G. (1994), 'On the speed and sequencing of privatisation and restructuring,' The Economic Journal, vol. 104, no. 426, pp. 1115-1168. https://doi.org/10.2307/2235073

Schimmelfennig, F. (2012), 'Europeanization beyond Europe,' Living Reviews in European Governance, vol. 7, no. 1, pp. 1-31.

Sedelmeier, U. (2008), 'After conditionality: post-accession compliance with EU law in East Central Europe,' Journal of European Public Policy, vol. 15, no. 6, pp. 806-825. https://doi.org/10.1080/13501760802196549

Thelen, K. (1999), 'Historical institutionalism in comparative politics,' Annual Review of Political Science, vol. 2, pp. 369-404. https://doi.org/10.1146/annurev. polisci.2.1.369

Vernygora, V.; Troitino, D. R. \& Västra, S. (2016), 'The Eastern Partnership programme: Is pragmatic regional functionalism working for a contemporary 
political empire?' in T. Kerikmae \& A. Chochia (eds.) Political and Legal Perspectives of the EU Eastern Partnership Policy, Cham: Springer, pp. 7-23. https://doi.org/10.1007/978-3-319-27383-9_2

Visionary Analytics (2017), Study on Research Cooperation in the Baltic Sea Region: Existing Networks, Obstacles and Ways Forward, Vilnius, 2017.

Williamson, O. E. (2000), 'The new institutional economics: Taking stock, looking ahead,' Journal of Economic Literature, vol. 38, no. 3, pp. 598-613. https://doi.org/10.1257/jel.38.3.595

Youngs, R. (2001), 'European Union democracy promotion policies: Ten years on,' European Foreign Affairs Review, vol. 6, no. 3, pp. 355-373.

https://doi.org/10.1023/A:1012424101504 